users have cause to be particularly grateful. We welcome a journal which may actually help to reduce the amount of literature that has to be read.

\section{Government Support for Civil Research}

IN the House of Commons on June 10, Mr. R. E. Prentice asked the Parliamentary Secretary to the Ministry of Works, as representing the Lord President of the Council, what steps he proposes to take to increase the scale of Government assistance for scientific research for civil purposes, in view of the concern expressed by the Council for Scientific and Industrial Research that its existing resources are too small. In a written answer, Mr. H. Nicholls said that in recent years the Government has been providing funds for scientific research on a steadily increasing scale, and the Lord President is now awaiting the proposals of the Council for the quinquennium ending March 31, 1964.

\section{Government Grants for University Building Pro- jects}

A QUESTION regarding the curtailment of projected university developments in building and proposed increases in scientific and technical teaching staff in the academic year 1958-59 in consequence of the inadequacy of the present quinquennial grant was raised in the House of Commons, and provoked a written reply on June 10. The Chancellor of the Exchequer was asked whether he would adjust the current grant to take account of the changing value of money, and in reply he pointed out that university buildings are financed by capital grants, which are quite separate from the quinquennial settlement of recurrent grant. Some universities may not be able to achieve in 1958-59 the increase in scientific and technical teaching staff which they had hoped; but, with the best will in the world, there must be a limit to the resources which can be made available even for expanding university facilities.

\section{The Soviet Contribution to the International Geophysical Year}

INFORMation BULLetin No. 4 of the Academy of Sciences of the U.S.S.R., 1958, contains in 122 pages the following (in Russian) : the report of the Bureau of the Special Committee of the International Geophysical Year, dated June 30, 1957, on the collection and storage of the results obtained; three reports on the construction, mode of operation and scientific tasks of the artificial Earth satellites (Sputniks 1 and $2)$; and a report on the working of recording marine buoys. These are followed by brief notes on the study of the inhomogeneity of the ionosphere, on the electrophotometric study of the luminosity of the night sky, and by a report of the special committee on the geographical distribution of observation points, organization of observations, exchange of information, timing and other subjects-a very detailed enumeration of the objects of study. Then there are reports of the Soviet Antarctic expedition for 1955-57, on the study of the variation of the magnetic field, on the conference of East European countries on the determination of local times, longitude and latitude, on the organization of special world intervals of observations and one on the fourth Antarctic Conference.

The Academy of Sciences of the U.S.S.R. has also published a bibliographical list (International Geophysical Year: Bibliographical Index of Literature in the Russian Language for 1954-1957) comprising more than 450 titles of books and articles dealing with the International Geophysical Year, which includes both scientific and popular scientific literature and works dealing with the complex Arctic and Antarctic expeditions organized in conjunction with the Geophysical Year. These publications are in Russian, but an English translation of the contents is given.

\section{Plastic Wrappers}

IN recent years plastics have been increasingly used in the home and in industry for the wrapping and storing of many different articles of food, and there is no doubt that these newer and convenient wrapping materials have effected a rapid transformation in food marketing and distribution and that they have made an important contribution to food hygiene. It is now recognized, however, that the term 'plastics' covers materials which cannot be regarded as chemically inert, and the British Plastics Federation has published a report (Report of the Toxicity Sub-Committee of the Main Technical Committee. Pp. 20. London: British Plastics Federation, 1958. 58.) for the guidance of manufacturers. The report is concerned solely with plastics that are to be used in association with foodstuffs and beverages; it is noted that the injudicious choice of raw materials for such plastics could conceivably affect the consumers of the foods concerned. It is proposed that manufacturers and converters of plastics should adopt a voluntary scheme for the examination of representative test pieces of materials intended for use with food, so that materials falling within the agreed specifications could be suitably labelled. Details are given of testing methods, involving first the extraction of materials under carefully controlled (including extreme) conditions designed to simulate the action of a stored food or beverage, and then the examination of extracts for toxicity.

\section{Atmospheric Pollution}

SiNCE 1914, regular climatological measurements of atmospheric pollution have been made by local authorities and 'co-operating bodies' in Britain. Sum. maries of their recent returns (The Investigation of Atmospheric Pollution : a Report on Observations in the Year ended 31st March, 1956. Pp. iv +123. London: H.M. Stationery Óffice, 1958. 7s. net) show the number of instruments in use to have increased from 1,722 to 2,113 in the past year. Their efforts would have seemed in vain if they were not accompanied by practical measures to control air pollution. News of such activities can be found elsewhere (Smokeless Air. Published by the National Society for Clean Air, No. 105. Spring 1958. 2s.), but the same report includes an account of progress at the Fuel Research Station on the abatement of atmospheric pollution from boilers, domestic heating, and metallurgical furnaces. When the Fuel Research Station at Greenwich moves to Stevenage later this year, its work on atmospheric pollution will be continued. This must surely add momentum to the implementation of the Clean Air Act, the full provisions of which come into force in England and Wales on June 1 .

\section{South African Research}

THE Register of Current Scientific Research at South African Universitios, 1956 (pp. vii +251. Pretoria: South African Council for Scientific and 